\title{
ALVÁSSAL A FELEJTÉS ELLEN? AZ ALVÁS SZEREPE AZ ASSZOCIÁCIÓS MEMÓRIAFOLYAMATOKBAN
}

\author{
CSÁBI Eszter, ZÁMBÓ Ágnes, PROKECZ Lídia
}

\author{
Szegedi Tudományegyetem, Pszichológia Intézet, Kognitív és Neuropszichológia Tanszék, Szeged
}

Hungarian | https://doi.org/10.18071/isz.73.0327 | www.elitmed.hu

\begin{abstract}
Háttér és cél - Számos bizonyíték utal arra, hogy az alvás szerepet játszik különböző emlékezeti rendszerek konszolidációjában. Kevesebbet tudunk arról, hogy milyen szerepe van az alvásnak a relációs memória múködésében, illetve az érzelmi arckifejezések felismerésében, holott ez olyan fundamentális kognitív képesség, amit mindennap használunk. Ezért kutatásunk célja annak feltérképezése, hogy az alvás milyen szerepet tölt be az asszociációs memória múködésében annak függvényében, hogy mikor történik a tanulás.
\end{abstract}

Módszerek - Vizsgálatunkban összesen 84 fő vett rész† [átlagéletkor: 22,36 (SD: 3,22), 21 férfi/63 nó], akiket két csoportra osztottunk: esti és reggeli csoportokra, utalva arra, hogy mikor történt a tanulás. Mindkét csoport esetében két tesztfelvétel volt, közvetlenül a tanulást követően (rövid távú tesztelés) és 24 órával később (hosszú távú tesztelés). A relációs memória vizsgálatára az arcok és nevek tesztet alkalmaztuk.

Eredmények - Sem az azonnali, sem a késleltetett tesztelés során nem találtunk különbséget a csoportok közöHt sem az általános tanulási mutatóban (arcokhoz társított nevekre való emlékezés érzelmi valenciától függetlenül), sem a különböző érzelmi arckifejezésekhez kapcsolódó nevekre való emlékezésben. Ezzel ellentétben, a csoporton belüli elemzés alapián a reggeli csoport a rövid távú teszteléshez képest nagyobb mértékú felejtést mutatott 24 órával később, a hosszú távú tesztelésen, míg az esti csoport ugyanolyan teljesítményt mutatott mindkét alkalommal. Emellett összefüggés jelent meg a teljesítmény, az alvásminőség, az alváshatékonyság és az alváslatencia között.

Következtetés - Eredményeink arra hívják fel a figyelmet, hogy az alvás és a tanulás időzítése fontos szerepet játszik az emlékek stabilizációjában, csökkentve ezzel a felejtés mértékét.

Kulcsszavak: alvás, relációs memória, érzelmi arckifejezések, felejtés, tanulás időzítése

\author{
THE ROLE OF SLEEP IN THE RELATIONAL MEMORY \\ PROCESSES \\ Csábi E, PhD; Zámbó Á; Prokecz L \\ Ideggyogy Sz 2020;73(9-10):327-337.
}

Background and purpose - A growing body of evidence suggests that sleep plays an essential role in the consolidation of different memory systems, but less is known about the beneficial effect of sleep on relational memory processes and the recognition of emotional facial expressions, however, it is a fundamental cognitive skill in human everyday life. Thus, the study aims to investigate the effect of timing of learning and the role of sleep in relational memory processes.

Methods - 84 young adults (average age: 22.36 (SD: 3.22), 21 male/63 female) participated in our study, divided into two groups: evening group and morning group indicating the time of learning. We used the face-name task to measure relational memory and facial expression recognition. There were two sessions for both groups: the immediate testing phase and the delayed retesting phase, separated by 24 hours.

Results - We failed to find differences neither between the groups nor in the general performance (number of correct answers independent of the emotional valence of facial expression) neither different emotional facial expressions in both sessions. In contrast, the within-subject analyses revealed to us that the morning group showed higher forgetting rates in the long term testing phase compared to the short term retest while the evening group showed similar performance in both retest phases. Moreover, we found a correlation between performance and sleep quality, sleep latency and sleep efficiency.

Conclusion - Our results suggest that the timing of learning and sleep plays an important role in the stabilizing process of memory representation to resist against forgetting.

Keywords: sleep, relational memory, emotional facial expressions, forgetting, timing of learning

Levelező szerző (correspondent): Dr. CSÁBI Eszter, Szegedi Tudományegyetem, Pszichológia Intézet;

6722 Szeged, Egyetem u. 2. Telefon: +36 62544 692, fax: +36 62544 509, e-mail: eszter.csabi@psy.u-szeged.hu

Érkezett: 2019. szeptember 10. Elfogadva: 2020. február 14. 


\section{Elméleti bevezetó}

A stabilitás-plaszticitás kérdése régóta foglalkoztatja a kognitív idegtudományt ${ }^{1}$, azaz: hogyan integráljuk az új információt a már meglévô ismeretek közé úgy, hogy a régi információk továbbra is hozzáférhetőek maradjanak ebben a dinamikusan változó környezetben. Napjainkra egyre több bizonyíték támasztja alá, hogy az alvás nemcsak a szervezet pihenését szolgáló globális inaktivitással jellemezhetô, hanem annak ideje alatt egy másfajta aktivitás is megjelenik, aminek fontos szerepe lehet az információstabilizációs folyamatban² .

A hosszú távú rögzülési folyamatban fontos tényező a tanulás időzítése, azaz hogy a nap mely szakaszában történik a tanulás, illetve hogy a tanuláshoz képest mikor következik be az alvás. Korábbi tanulmányok alapján jobb teljesítmény jelenik meg hosszú távon, ha a tanulás az alvás előtt történik, mint ha alvást követően; ezen kutatások alapján a későbbi emlékezeti teljesítmény szempontjából nincs jelentősége, hogy mikor történik a tanult anyag újratesztelése ${ }^{3-5}$. Hazai vonatkozásban Szôlloósi és munkatársai ${ }^{5}$ a napszak hatását vizsgálták az önéletrajzi emlékezet múködésére. Vizsgálatukban önéletrajzi emlékek (aznapi vagy előző napi események) felidézését kérték öt napon keresztül, majd 30 nappal később ezeknek az eseményeknek az ismételt felidézésére kérték a vizsgálati személyeket. Eredményeik szerint, akik este, alvás előtt idézték fel először az autobiografikus emlékeket, 30 nappal később jobb teljesítményt mutattak az ismételt felidézés során, azokhoz képest, akiknél alvást követően, reggel történt az elsô felidézés. Vizsgálatukban tehát az önéletrajzi események hosszú távú felidézése attól függött, hogy ezeket az eseményeket korábban mikor idézték fel először, közvetlenül alvás előtt vagy ébredés után. Következtetésük, hogy nem a tanulás és a tesztelés között eltelt idő számít a későbbi sikeres felidézés szempontjából, hanem, hogy a következô alvási szakasz mennyivel követte a felidézést ${ }^{5}$.

Az alvás konszolidációban betöltött jótékony hatásának magyarázata lehet, hogy olyan neurokémiai és neuroanatómiai változások következnek be alvás alatt, amelyek kedveznek az információk hosszú távú stabilizációjának, ellenállóvá téve ezzel az emléknyomot az interferenciával és a felejtéssel szemben ${ }^{6}$. A tanult ismeretek rögzülése már az ébrenlét során megkezdődik, azonban ez egy gyors feldolgozást és átmeneti tárolást eredményez, ezért mindenképpen szükség van egy lassabb stabilizációs folyamatra, amelynek optimális ideje az alvás, hiszen ilyenkor a külvilágból érkező ingerlés mini- málisra csökken. Így a már korábban, az ébrenlét során kódolt információk újraaktiválódhatnak és átszerveződve beépülhetnek a már meglévő emléknyomok közé. Ebben az alvás alatti konszolidációs folyamatban a hippocampus és a kérgi területek közötti reciprok kommunikáció érintett ${ }^{7,8}$.

A hosszú távú rögzülés szempontjából a tanulás időzítésén kívül egy másik fontos faktor az érzelmi valencia. Atienza és munkatársai ${ }^{9}$ szerint az érzelmek és az alvás egymástól független moduláló tényezők, amelyek eltérôképpen befolyásolhatják az emlékezeti konszolidációs folyamatot. Az érzelmileg telített eseményekre alapvetően jobban emlékezünk, mert relevánsabbak a jövőbeli viselkedés szempontjából ${ }^{10}$. Ébrenlét alatt priorizáljuk azokat az információkat, amelyek fontosak lehetnek a jövőben, és elsősorban ezek fognak újraaktiválódni és stabilizálódni alvás alatt ${ }^{11}$. Ennek a priorizálási folyamatnak lehetnek az eszközei az érzelmek, amelyek facilitálhatják a kódolást, és módosíthatják a rögzülési folyamatot azáltal, hogy az érzelmek által „,címkézett” releváns ismereteket kiszelektáljuk alvás alatt az irreleváns ingerek közül, és ezek konszolidálódnak elsődlegesen ${ }^{11-14}$.

Az alvás tehát szelektál, és a jövőbeli relevancia alapján elsôsorban azokat az emléknyomokat erôsíti meg a felejtéssel szemben, amelyek érzelmileg kiugróak $^{13}$. Ez a hatás megjelenhet pozitív ingerek esetében, mert ezek jutalmazó értékúek lehetnek, illetve negatív ingerek esetén, hiszen a negatív ingerekre való emlékezés a túlélést szolgálhatja ${ }^{12}$. Ezt bizonyítják azok a kutatások is, amelyek jobb emlékezeti teljesítményt találtak alvást követôen negatív ingeranyagok esetében, attól függetlenül, hogy verbális (például szólista) vagy vizuális (például képek) feladatot alkalmaztak ${ }^{14-18}$.

Az érzelmek kifejezésének egyik elsődleges eszközei az arckifejezések, amelyek felismerése és értelmezése olyan fundamentális kognitív képességek, melyek elengedhetetlenek a szociális interakciókban. Vannak eredmények arra vonatkozólag, hogy az érzelmeket kifejező arcokra jobban emlékezünk, mint a semleges arcokra. Több tanulmány is utal arra, hogy a pozitív érzelmeket (például mosolygós, boldog arcok) könnyebben és gyorsabban felismerjük ${ }^{19}$, illetve jobban emlékezünk ${ }^{20,21}$ rájuk. Winston és munkatársai ${ }^{22}$ szerint azért, mert a pozitív szociális visszajelzések jutalmazó értékúek, ha mosolygós embereket látunk, sokkal megbízhatóbbnak, kedvesebbnek, vonzóbbnak ítéljük őket. Ezzel ellentétben, a negatív érzelmek sokszor heterogénebbek, komplexebbek, sok esetben rosszul kifejezettek lehetnek, ami megnehezítheti gyors azonosításukat ${ }^{23}$. 
Az intakt érzelmi arckifejezésekben ${ }^{24}$ és ezek felismerésében ${ }^{25}$ fontos szerepet tölt be az alvás. Maccari és munkatársai ${ }^{26}$ az alvásdepriváció hatását nézték az érzelmeket kifejező arcok, valamint érzelmileg telített verbális ingerek felismerésére. Eredményeik alapján az alvásdeprivált csoport esetében a szavak felismerése érzelmi telítettségtől függetlenül romlást mutatott. Az arckifejezések felismerése esetében pedig fóként a semleges arcoknál jelent meg csökkent teljesítmény (csökkent pontosság és megnövekedett válaszlatencia). Az érzelmeket mutató arcokra való emlékezés lényegesen rezisztensebb volt az alvásdepriváció káros hatásaival szemben, különösen a pozitív érzelmeket kifejező arcok esetében. Pallesen és munkatársai ${ }^{27}$ szintén az érzelmeket kifejezô arcokra való emlékezést vizsgálták alvásdeprivációt követően úgy, hogy külön vizsgálták a jobb és bal féltekei feldolgozási folyamatokat. Ehhez a fixációs ponthoz képest jobb vagy bal oldalon jelenítették meg a célingert. Eredményeik hasonlóan alakultak Maccari és munkatársai ${ }^{26}$ eredményeihez: az alvásdeprivált csoport megnövekedett válaszlatenciát és csökkent pontosságot mutatott az arcok felismerésében, fóként a jobb féltekei feldolgozás esetében.

Fontos megjegyezni, hogy az eddig bemutatott vizsgálatok az alvásdepriváció hatását nézték az érzelmi arckifejezésekre való emlékezésre. Vizsgálatunkban nem alkalmaztunk alvásmegvonást, hanem a tanulási periódus időzítésével vizsgáltuk az alvás hatását úgy, hogy az egyik csoport este tanult és teszteltük először (a továbbiakban esti csoport, utalva arra, hogy mikor történt a tanulás és az első tesztelés), majd 24 órával később, másnap este történt a hosszú távú, második tesztelés. A másik csoport pedig reggel tanult és teszteltük először (a továbbiakban reggeli csoport, utalva arra, hogy mikor történt a tanulás és az azonnali tesztelés), majd 24 órával késóbb, másnap reggel került sor a második, hosszú távú tesztelésre. Az eddig bemutatott tanulmányoktól eltérôen, vizsgálatunkban az asszociatív emlékezet mérésére az arcok-nevek tesztet alkalmaztuk, amelynek során a tanulási fázisban a résztvevốk érzelmeket kifejező és semleges arcokat láttak nevekkel párosítva, majd mindkét tesztfázisban csak az arcokat látták és fel kellett idézniük az adott archoz korábban kódolt nevet.

Kevesebb olyan vizsgálat található a szakirodalomban, ami hasonló elrendezésben, hasonló feladattal, nem alvásdeprivációs paradigmával vizsgálta az alvás és az érzelmek moduláló hatását az asszociatív memória múködésére. Tsukiura és Cabeza $a^{21}$ vizsgálatában a résztvevóknek pozitív (mosolygós) és semleges arcokhoz társított gyakori neveket kellett megtanulniuk, majd felidézniük úgy, hogy a felidézési fázisban már csak a neveket látták és a hozzájuk tartozó érzelmi arckifejezéseket kellett megnevezniük. Eredményeik alapján a pozitív arcoknál sokkal gyorsabb és pontosabb volt a felidézés, ami a hippocampus és az orbitofrontális kéreg aktivitásfokozódásával függött össze, mind a tanulási, mind a felidézési fázisban. E két terület funkcionális konnektivitása alapján a szerzôk feltételezése, hogy a jutalmazó rendszer, amelynek része az orbitofrontális kéreg, modulálhatja az arcnév asszociáció kialakulásáért felelős relációs emlékezeti múködést, ami a hippocampus által vezérelt folyamat ${ }^{21}$.

A korábbi szakirodalmi előzményekre alapozva kutatási kérdésünk, hogy az alvás milyen szerepet tölt be az asszociációs memória múködésében annak függvényében, hogy mikor történik a tanulás, az alvási szakasz előtt vagy azt követően. Feltételezésünk, hogy az esti csoport, amelyik a tanulás és rövid távú tesztfázis után közvetlenül aludhatott, jobb összteljesítményt fog mutatni, tehát több archoz társított névre fog emlékezni érzelmi valenciától függetlenül, mind az azonnali, mind a késleltetett tesztfázisban. Második hipotézisünk, hogy az esti csoport az érzelmeket mutató arcokhoz társított nevek esetében is jobb emlékezeti teljesítményt fog mutatni azonnal és 24 órával késóbb is, mint a reggeli csoport.

\section{Módszerek}

\section{VIZSGÁLATI SZEMÉLYEK}

A vizsgálatban összesen 84 fiatal felnőtt vett részt, 21 férfi és 63 nô. A résztvevők átlagéletkora 22,36 év (SD: 3,22), az iskolai végzettség átlaga 15,48 év (SD: 2,37) (iskolában eltöltött évek számának átlaga). A vizsgált mintát két csoportra osztottuk, mindkét csoport esetében két adatfelvételre került sor. Az esti csoport esetében este volt a tanulási és az elsố teszt fázis, a második tesztelés pedig 24 órás késleltetéssel, másnap este történt. A reggeli csoportnál reggel történt a tanulás és az első teszt, és 24 órával később, másnap reggel az újratesztelés. A csoportokat egyeztettük életkorban $[t(82)=0,538, p$ $=0,59]$, iskolai végzettségben $[t(82)=0,274, p=$ $0,78]$ és komplex munkamemória teljesítményben $[t(82)=-1,078, p=0,28]$ (Fordított Számterjedelem Teszt $)^{28}$. Az alvásváltozók tekintetében nem találtunk szignifikáns különbséget a csoportok között a Pittsburgh Szubjektív Alvásminőség Kérdőív ${ }^{29}$ egyes dimenziói mentén: szubjektív alvásminőség 
$[t(82)=0,356, p=0,72]$, alváslatencia $[t(82)=$ $-0,474, p=0,63]$, alvásidőtartam $[t(82)=0,000, p$ $>0,99$ ], alváshatékonyság [ $t(82)=0,000, p>0,99]$, alvászavarok $[t(82)=0,946, p=0,34]$ és a kérdőíven elért összpontszám tekintetében $[t(82)=0,215$, $p=0,83]$. Szintén nincs különbség a csoportok között sem a tanulás előtti [ $t(82)=0,378, p=0,7]$, sem a tanulás utáni szubjektív alvásidô megítélésében $[t(82)=1,546, p=0,12]$, valamint a tanulás és felidézés közötti éjszakai alvás minőségének szubjektív megítélésében, amelyet a Groningen Alvásminőség Skálával ${ }^{30}$ mértünk $[t(82)=-0,423$, $p=0,67]$. A kronotípus meghatározására a MEQ $\mathrm{H}$ (Morningness Eveningness Questionnaire) ${ }^{31}$ kérdôívet alkalmaztuk, amely alapján a két csoport nem tért el egymástól napszaki aktivitásmintázat tekintetében $[t(82)=-0,450, p=0,65]$. Mind a tanulás, mind a felidézés előtt a csoportok résztvevôi kitöltötték a Stanford Álmossági és Fáradtsági Skálákat ${ }^{32}$. Egyik esetben sem találtunk szignifikáns különbséget a csoportok között, sem a tanulás előtti álmosság $[t(82)=0,176, p=0,243]$ és fáradtság $[t(82)=1,768, p=0,08]$ mértékében, sem a felidézés előtti álmosság $[t(82)=0,187, p=0,85]$ és fáradtság $[t(82)=-0,634, p=0,52]$ szintjében. A csoportok összehasonlítására vonatkozó eredmények átlagértékeit az 1. táblázat tartalmazza.

A vizsgálati személyek önkéntesen vettek részt a vizsgálatban, aminek megkezdése elôtt írásban és szóban is tájékoztattuk őket a vizsgálat céljáról és menetéről, illetve írásbeli beleegyezést is kértünk tőlük. A vizsgálat során betartottuk az SZTE Pszichológia Intézet és az Egyesített Pszichológiai Kutatásetikai Bizottság (EPKEB) által előírt etikai szabályokat (EPKEB etikai engedély referenciaszáma: 2019/5).
VIZSGÁLATI ESZKÖZÖK

\section{Szubjektív alvásminóség vizsgálata}

Pittsburgh Alvásminöség Index (PSQI - Pittsburgh Sleep Quality Index)

A Pittsburgh Alvásminőség Index egy 11 tételből álló önkitöltő kérdőív, ami az előzó egy hónapra vonatkozó szubjektíven megélt alvásminőséget méri. A kérdőív öt dimenziót mér: szubjektív alvásminőség, alváslatencia, alvásidôtartam, alváshatékonyság, alvászavarok. A tesztet kitöltőnek az egyes állításokat az előfordulási gyakoriság szempontjából kell értékelnie egy négyfokú Likertskálán ${ }^{29}$.

\section{Gröningen Alvásminôség Skála}

A Gröningen Alvásminőség Skála egy 15 állítást tartalmazó önkitöltő kérdőív, ami az előzó éjszakai alvás minőségére kérdez rá. A teszt kitöltése során a kitöltőnek az adott állításról kell eldönteni, hogy igaz vagy hamis-e rá vonatkozólag az adott állítás ${ }^{30}$.

\section{Stanford Álmosság és Fáradtság Skálák}

Hét-hét kijelentést tartalmazó skálák, amelyek az aktuális álmosság és fáradtság szintjét határozzák meg. A kitöltố feladata, hogy az aktuálisan megélt fáradtság és álmosság szintjére legjellemzőbb állítást jelölje meg $^{32}$.

\section{Napszaki preferenciák mérése}

A napszaki preferenciák mérésére a Morningness Eveningness Questionnaire (MEQ) magyar nyelvú változatát a MEQ-H-t használtuk: A kérdőív 19 tételből áll, amelyre a vizsgálati személyeknek egy négyfokú Likert-skálán kell válaszolniuk. A teszt

1. táblázat. Alváskérdőiveken elért átlag pontszámok értékei a csoportokban

\begin{tabular}{|lll|}
\hline Alváskérdő́ivek & M (SD) & \\
\hline & Esti csoport & Reggeli csoport \\
\hline PSQI - szubjektív alvásminőség & $0,57(0,70)$ & $0,52(0,50)$ \\
PSQI - alváslatencia & $1,60(1,17)$ & $1,71(1,13)$ \\
PSQI - alvásidő́tartam & $0,64(0,75)$ & $0,64(0,69)$ \\
PSQI - alváshatékonyság & $0,21(0,60)$ & $0,21(0,60)$ \\
PSQI - alvászavarok & $0,69(0,64)$ & $0,57(0,50)$ \\
PSQI - összpontszám & $3,81(2,15)$ & $3,71(1,90)$ \\
Alvásóra - tanulás elótt (órában) & $7,40(1,72)$ & $7,27(1,43)$ \\
Alvásóra - felidézés elő́tt (órában) & $7,27(1,23)$ & $6,84(1,30)$ \\
Groningen Alvásminóség Skála & $6(4,63)$ & $6,43(4,64)$ \\
MEQ - H & $48,26(7,70)$ & $49,14(10,06)$ \\
Stanford Álmosság Skála - tanulás előtt & $2,50(1,11)$ & $2,21(1,11)$ \\
Stanford Fáradtság Skála - tanulás elótt & $2,71(1,08)$ & $2,33(0,87)$ \\
Stanford Álmosság Skála - felidézés elő́tt & $2,67(1,09)$ & $2,62(1,22)$ \\
Stanford Fáradtság Skála - felidézés előtt & $2,55(0,73)$ & $2,69(1,25)$ \\
\hline
\end{tabular}


három napszaki aktivitásmintázatot különít el: esti típusú, reggeli típusú és köztes típusú személyeket ${ }^{31}$.

\section{Komplex munkamemória vizsgálata}

A komplex munkamemória mérését a Fordított Számterjedelem Teszttel mértük, amelynek során a vizsgálati személynek a vizsgálatvezetô által felsorolt számsorozatokat kell fordított sorrendben megismételni. A feladat összesen kilenc számjegyet tartalmazó terjedelemből áll, minden terjedelemhez négy próba tartozik, amiből legalább kettốt helyesen meg kell ismételnie a vizsgálati személynek ahhoz, hogy a következő terjedelemre léphessen. Csak a helyesen fordítva visszamondott sorozat fogadható el, a felcserélés vagy kihagyás hibának számít. Az utolsóként helyesen visszamondott sorozat mutatja a személy komplex munkamemória-terjedelmét ${ }^{28}$.

\section{Az asszociatív emlékezet vizsgálata}

Korábbi kutatásokat alapul véve ${ }^{33}$, az asszociatív emlékezet mérésére egy 48 arc-név párból álló listát használtunk (1. ábra). A feladathoz a képi ingereket hivatalos arckép adatbázisból választottuk ki: CAL/PAL Face Database ${ }^{34}$, Equating young \& old faces $^{35}$, NimStim ${ }^{36}$. Mindegyik arckép szemből ábrázolja a személyeket, akiknek az életkora 19-32 év közé esik, kaukázusiak és semmilyen szembeötlő vizuális sajátosságuk nincs (például szakáll, bajusz, anyajegy, szemüveg, ékszer stb.). A bemutatott arcok fele férfi, másik fele pedig nő. Valamennyi megjelenített kép fehér hátterú, fekete-fehér árnyalatos volt, a szükséges módosításokat Adobe Photoshop (Adobe System) segítségével végeztük el. Az arcképek egyenlő arányban tartalmaztak pozitív (boldog), negatív (szomorú) és semleges érzelmi töltéssel rendelkezô arcokat (kategóriánként 16 pár).

Az arcokhoz rendelt nevek maximum három szótagúak voltak, illetve a 2000 és 2015 között leggyakrabban anyakönyvezett nevek listájából lettek kiválasztva, az MTA Nyelvtudományi Intézet (http://www.nytud.mta.hu/oszt/nyelvmuvelo/utonevek/index.html) és a Magyar Keresztnevek Tárának (http://magyarnevek.hu/nevek/utonevstatisztika) weboldalairól.

\section{ELJÁRÁS}

A vizsgálatban résztvevőket két csoportra osztottuk, mindkét csoport esetében volt egy tanulási és egy azonnali tesztelés, valamint egy felidézési fázis 24 órával később. Az esti csoport esetében a tanulás és azonnali teszt este 20:00 és 21:00 között zajlott, a felidézés pedig 24 órával később, másnap este 20:00

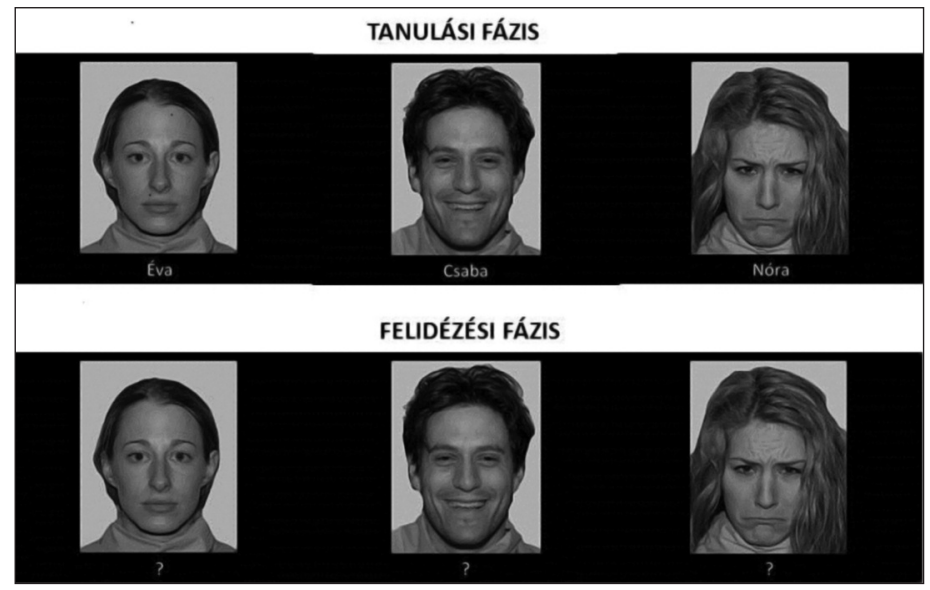

1. ábra. A vizsgálatban használt arc-név feladat, amelynek során a vizsgálati személyek a tanulási fázisban meghatározott sorrendben, két alkalommal láttak 48 db (16 semleges, 16 pozitív, 16 negatív), érzelmi arckifejezést mutató arcot, amelyek mindegyikéhez egy név tartozott. A felidézési fázisban egy alkalommal, random sorrendben látták a résztvevók az arcokat, feladatuk az volt, hogy emlékezzenek vissza az arcokhoz tartozó nevekre

és 21:00 között. A reggeli csoport esetében a tanulás és elsố tesztelés reggel 8:00 és 9:00 között történt, a felidézés pedig 24 órás késleltetéssel, másnap reggel 8:00 és 9:00 között. Korábbi kutatások alapján ${ }^{33}$, a tanulási fázisban a vizsgálati személyek az arc-név feladatot két alkalommal látták, majd ezt követte az azonnali felidézés. Az arcképek meghatározott sorrendben jelentek meg, 5 másodperces exponálási idővel, egy arckép csak egy alkalommal jelent meg a bemutatás során. A második bemutatást követően történt az azonnali felidézés, amelynek során arra kértük a vizsgálati személyeket, hogy próbálják meg felidézni az arcképekhez tartozó neveket. Ebben az esetben már random módon jelentek meg a képek a sorrendi hatás elkerülése miatt, illetve a személyek gombnyomással saját maguk szabályozhatták az arcképek megjelenésének idejét. A feladatuk az volt, hogy hangosan kimondják azt a nevet, amelyet korábban láttak az arcképpel párosítva. A válaszokat egy adatlapon rögzítettük, a vizsgálati személyek csak a helyes név esetén kaptak pontot, amennyiben rossz nevet mondtak vagy nem emlékeztek a névre, nem járt pont.

A második alkalommal, 24 órás késleltetést követően szintén random sorrendben látták a személyek a képeket, a feladatuk pedig ismét az volt, hogy próbáljanak meg visszaemlékezni, és mondják ki hangosan az arcképpel korábban látott nevet. Az arcképek megjelenését szintén saját maguk szabályozhatták egy gomb lenyomásával.

Mindkét adatfelvétel nyugodt körülmények között, az SZTE Pszichológia Intézet Kardos-laborjában zajlott. Mindkét adatfelvétel megközelítőleg 


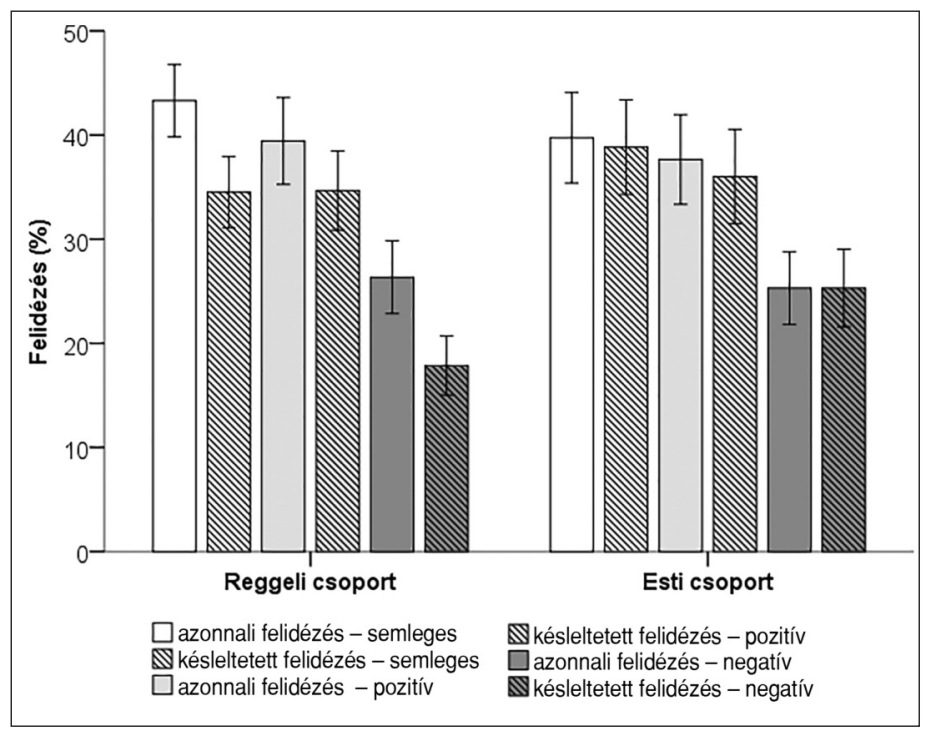

2. ábra. A csoportok teljesítményének összehasonlítása az azonnali és a késleltetett felidézési fázisban: Nincs szignifikáns különbség a csoportok között sem az azonnali, sem a késleltetett felidézési fázisban, sem az összesített felidézési mutatóban (helyesen felidézett arcokhoz társított nevek száma érzelmi telitettségtöl függetlenül), sem a pozitív, negatív és semleges arcokhoz társított nevek felidézésében. A csoportokon belül az azonnali felidézéshez. képest a reggeli csoport nagyobb felejtést mutatott, érzelmi telítettségtôl függetlenül, mint az esti csoport, amely esetében nem jelent meg szignifikáns különbség a teljesítményben a két felidézési alkalom között. A hibasávok a standard hibát mutatják (SEM)

egy órát vett igénybe. A Stanford-skálákat minden alkalommal kitöltettük a vizsgálat megkezdése előtt a személyekkel, a Fordított Számterjedelem Teszt felvétele elsố alkalommal, a PSQI és a Groningen tesztek kitöltése a második alkalommal történt.

\section{ADATELEMZÉS}

Az adatok elemzését kevert elrendezésú varianciaanalízissel végeztük. Amennyiben a szfericitási feltétel nem teljesült, a Greenhouse-Geisser korrigált értékeket vettük figyelembe. A post hoc teszteket Bonferroni-korrekcióval végeztük. A közölt hatásnagyságok a főhatások és interakciók esetében a parciális $\eta^{2}$-mutatók.

\section{Eredmények}

RÖVID ÉS HOSSZÚ TÁVÚ FELIDÉZÉSI TELJESÍTMÉNY ÖSSZEHASONLÍTÁSA A KÉT CSOPORT KÖZÖTT

Az első alkalommal, a RÖVID TÁVÚ (AZONNALI) FELIDÉZÉSI fázisban az ismételt méréses varianciaanalízis alapján nem találtunk különbséget a csoportok között az összesített tanulási mutatóban (összes helyes válasz száma érzelmi telítettségtől függetlenül) [CSOPORT főhatás: $F(1,82)=0,165$, $p=0,68, M_{\text {esti csoport }}: 16,43$ (SD: 12,01$)$ vs. $M$ : 17,45 (SD: 11,03)]. Emellett nem találtunk szignifikáns különbséget a csoportok között a különböző érzelmi töltéssel rendelkező arc-név párok esetében sem [CSOPORT $\times$ ÉRZELEM interakció: $\mathrm{F}(1,82)=0,393, p=0,67$; pozitív arc-név párok: $M_{\text {esti }}: 6,02$ (SD: 4,44) vs. $M_{\text {reggeli csoport }}: 6,31$ (SD: 4,32), negatív arc-név párok: $M_{\text {esti csoport }}^{4,05}$ (SD: 3,62 ) vs. $M_{\text {reggeli csoport }} 4,21$ (SD: 3,61 , semleges arcnév párok: $M_{\text {esti csoport: }}^{\text {reggeli csoport }}$ 6, (SD: 4,51) vs. $M$ : 6,93 (SD: 3,58)] (2. ábra).

A második alkalommal, a HOSSZÚ TÁVÚ (KÉSLELTETETT) FELIDÉZÉSI fázisban, 24 órával később szintén nem jelent meg szignifikáns különbség a csoportok között az összesített tanulási mutatóban (összes helyesen felidézett arc-név pár, az érzelmi telítettségtôl függetlenül) [CSOPORT foóhatás: $\mathrm{F}(1,82)=0,708, p=0,403, M_{\text {esticsport }}: 16,02$ (SD: 12,83$)$ vs. $M_{\text {reggeli csoport }}$ : 13,93 (SD: 9,78)]. Nem találtunk különbséget a különböző érzelmi töltéssel rendelkező arc-név párok esetében sem [CSOPORT $\times$ ÉRZELEM interakció: $F(1,82)=$ 2,141, $p=0,12$; pozitív arc-név párok: $M_{\text {esti csoport }}$ : 5,76 (SD: 4,70) vs. $M_{\text {reggeli csoport }}: 5,55$ (SD: 3,94), negatív arc-név párok: $M_{\text {esti csoport }}^{\text {cot }} 4,05$ (SD: 3,87 ) vs. $M_{\text {reggeli csoport }} 2,86$ (SD: 2,95), semleges arc-név párok: $M_{\text {esti csoport: }}^{6,21}(\mathrm{SD}: 4,70)$ vs. $M_{\text {reggeli csoport }}$ : 5,52 (SD: 3,54) az alvós és az ébrenléti csoportok között] (2. ábra).

\section{TANULÁSI ÉS FELIDÉZÉSI TELJESÍTMÉNY ÖSSZEHASONLÍTÁSA A CSOPORTOKON BELÜL}

A felidézési teljesítmény vizsgálatához egy FELIDÉZÉS (azonnali vagy késleltetett) $\times$ ÉRZELEM (semleges, pozitív, negatív arckifejezés) $\times$ CSOPORT (Reggeli csoport, Esti csoport) $2 \times 3 \times 2$ kevert elrendezésú ANOVA-t végeztünk. A CSOPORT főhhatás nem volt szignifikáns, azaz a két csoport összteljesítménye nem tért el jelentôsen egymástól, $F(1,82)=0,046, \mathrm{MSE}=3393,698, p=$ $0,830, \eta p^{2}=0,001$. A FELIDÉZÉS főhatás szignifikánsnak bizonyult, $F(1,82)=62,009$, MSE = $34,028, p<0,001, \eta p^{2}=0,432$; az azonnali felidézés során jobb teljesítmény volt tapasztalható összességében, mint a késleltetett felidézés során. Ez azonban nem azonos módon érvényesült a két csoportban, amit a FELIDÉZÉS $\times$ CSOPORT kereszthatás jelzett, $F(1,82)=39,087$, MSE = $34,028, p<0,001, \eta p^{2}=0,323$. A post hoc tesztek eredményei szerint a kereszthatás annak volt köszönhetô, hogy míg az esti csoport teljesítménye nem változott jelentôsen a késleltetést követően ( $p$ 
$=0,255)$, addig a reggeli csoportnál szignifikáns csökkenés volt megfigyelhető $(p<0,001)$. A két csoport teljesítménye egyik felidézésnél sem különbözött egymástól jelentősen (mindkét $p>0,402$ ).

Az ÉRZELEM főhatása is szignifikáns volt, $F(2$, $164)=75,280, \operatorname{MSE}=155,203, p<0,001, \eta p^{2}=$ 0,479 , jelezve, hogy a semleges, pozitív és negatív arcokhoz nem azonos sikerrel társították a neveket a résztvevők. A post hoc tesztek eredményei szerint a semleges és pozitív arcoknál megfigyelhető teljesítmény nem tért el egymástól $(p=0,320)$, ám mindkettő szignifikánsan magasabb volt, mint a negatív arcoknál megfigyelhetô teljesítmény (mindkét $p<0,001)$. Fontos, hogy sem a ÉRZELEM $\times$ CSOPORT, sem az ÉRZELEM $\times$ FELIDÉZÉS kereszthatások nem voltak szignifikánsak (mindkét $p>$ 0,337), jelezve, hogy a fenti hatás összességében azonos módon nyilvánult meg mindhárom csoportban és mindkét felidézés esetén. Végül, a FELIDÉZÉS $\times$ ÉRZELEM $\times$ CSOPORT hármas interakció szignifikáns volt, $F(2,164)=3,427$, MSE = $26,412, p=0,035, \eta p^{2}=0,040$. A post hoc tesztek szerint ennek az volt az oka, hogy míg az esti csoportban egyik valencia esetében sem tért el az azonnali és a késleltetett felidézési teljesítmény (minden $p>0,187$ ), addig a reggeli csoportban mindhárom valencia esetén szignifikáns csökkenés volt tapasztalható (minden $p<0,001$ ); az eredményeket a 2. ábra szemlélteti.

\section{KORRELÁCIÓELEMZÉSEK A TANULÁSI ÉS FELIDÉZÉSI FÁZISBAN}

\section{Korrelációelemzés az azonnali felidézés során}

Az azonnali felidézés során a Pearson-féle korrelációelemzés alapján közepesen erôs negatív korreláció jelent meg az összesített tanulási mutatóval, valamint a Groningen Alvásminőség Skála által mért, a tanulást megelőző éjszaka alvására rákérdezô szubjektív alvásminőséggel $[r(82)=-0,577, p<$ $0,001]$. Ez a közepesen erós negatív korreláció a Groningen Alvásminőség Skálával kimutatható volt a mind a pozitív $[r(82)=-0,592, \mathrm{p}<0,001]$, mind a negatív $[r(82)=-0,487, p<0,001]$, mind a semleges $[r(82)=-0,563, p<0,001]$ arc-név párok esetében is.

A Pittsburgh Szubjektív Alvásminőség (PSQI) dimenziói közül erôs negatív összefüggés jelent meg az összesített tanulási mutató és az alváslatencia között $[r(82)=-0,734, p<0,001]$, illetve az alváslatencia a pozitív $[r(82)=-0,734, p<0,001]$, negatív $[r(82)=-0,721, p<0,001]$ és semleges $[r(82)=-0,713, p<0,001]$ arc-név párok tanulásával is erôs negatív korrelációt mutatott. Emellett közepesen erôs negatív korreláció jelent meg a PSQI alváshatékonyság alskálája és az összesített tanulási mutató között $[r(82)=-0,352, p=0,001]$, illetve ezen belül a pozitív $[r(82)=-0,321, p=$ $0,003]$, negatív [ $r(82)=-0,330, p=0,002]$ és semleges $[r(82)=-0,357, p=0,001]$ arc-név párok tanulása esetében is. Továbbá a PSQI összesített mutatója mutatott közepesen erôs negatív korrelációt az összesített tanulási teljesítménnyel $[r(82)=$ $-0,421, p<0,001]$, illetve a pozitív $[r(82)=-0,434$, $p<0,001]$, negatív $[r(82)=-0,366, p<0,001]$ és semleges $[r(82)=-0,398, p<0,001]$ arc-név párok tanulásával.

\section{Korrelációelemzés a késleltetett felidézési fázis során}

A késleltetett felidézési fázisban a Pearson-féle korrelációelemzés alapján, az azonnali felidézési fázishoz hasonlóan, közepesen erôs, negatív összefüggés jelent meg az összesített felidézési mutató (összesen helyesen felidézett arc-név pár, érzelmi telítettségtől függetlenül) és a Groningen Alvásminőség Skála között $[r(82)=-0,520, p<0,001]$, ami közepesen erős negatív korrelációt mutatott a pozitív [ $r(82)=-0,549, p<0,001]$, negatív $[\mathrm{r}(82)=$ $-0,441, \mathrm{p}<0,001]$ és semleges $[r(82)=-0,486, p<$ 0,001] arc-név párokra vonatkozó emlékezeti teljesítménnyel is.

A Pittsburgh Alvásminőség Index (PSQI) alskálái közül az alváslatencia mutatott erôs korrelációt az összesített felidézési mutatóval $[r(82)=-0,691$, $p<0,001]$, valamint a pozitív $[r(82)=-0,709, p<$ $0,001]$, negatív $[r(82)=-0,557, p<0,001]$ és semleges $[r(82)=-0,692, p<0,001]$ arc-név párokra való emlékezeti teljesítménnyel. Szintén közepes erôsségú, negatív korreláció jelent meg az összesített felidézési mutató $[r(82)=-0,336 p=0,002]$, ezen belül a pozitív $[r(82)=-0,351, p=0,001]$, negatív $[r(82)=-0,284, p=0,023]$ és semleges arcnév párok $[r(82)=-0,349, p=0,001]$ és a PSQI alváshatékonyság alskála között. A PSQI összesített pontszám is közepesen erős negatív összefüggést mutatott az összesített felidézési mutatóval $[r(82)=-0,379, p<0,001]$, illetve a pozitív $[r(82)$ $=-0,424, p<0,001]$, negatív $[r(82)=-0,250, p<$ $0,001]$ és semleges arc-név párok $[r(82)=-0,389, p$ $<0,001]$ felidézésének számával.

\section{Megvitatás}

Kutatásunk célja annak vizsgálata volt, hogy az alvás milyen szerepet tölt be az asszociációs memória múködésében a tanulás időzítésének függ- 
vényében. Eredményeink alapján sem a rövid távú, azonnali, sem a hosszú távú, 24 órával későbbi felidézési fázisban nem találtunk szignifikáns különbséget a csoportok között, sem az összesített tanulási mutatóban, sem a különböző érzelmi arckifejezésekhez társított nevek tanulási és felidézési mutatóiban. A csoporton belüli eredmények vizsgálatakor azt állapítottuk meg, hogy az a csoport, amelyik reggel tanult, a hosszú távú tesztelésen többet felejtett ahhoz a csoporthoz képest, amelynél este történt a tanulás. Ezzel ellentétben, az esti csoportnál nem jelent meg ez a felejtési mechanizmus, közel ugyanúgy teljesítettek az azonnali és a 24 órával későbbi felidézéskor. Mindkét fázisban ugyanazokat az összefüggéseket találtuk, az előzó éjszakai alvásminőség összefüggést mutatott a következő napi tanulási és felidézési teljesítménnyel, érzelmi valenciától függetlenül. Az alváslatencia, a szubjektíven megélt alváshatékonyság és alvásminőség szintén korrelációt mutatott mind a tanulási, mind a felidézési teljesítménnyel.

$\mathrm{Az}$ alvás emlékezeti konszolidációban betöltött szerepével foglalkozó kutatások jelentős többsége nagyobb teljesítményjavulást mutatott ki abban az esetben, amikor a tanulás alvás előtt történt, illetve a tanulás és felidézés között aludtak a résztvevők, azzal a csoporttal szemben, akiknél alvást követően történt a tanulás, és a felidézésig eltelt időt ébrenléttel töltötték ${ }^{3,14,15}$. Kutatásunkban nem találtunk különbséget az este és reggel tanuló csoportok között a helyesen felidézett nevek arányában, sem a rövid távú azonnali, sem a hosszú távú felidézés alkalmával. Habár az alvás hatására nem jelent meg teljesítményjavulás az esti csoportnál, az emléknyomok hosszú távú stabilizációjára utal, hogy a reggeli csoport nagyobb felejtést mutatott a hosszú távú felidézésnél az azonnali felidézéshez képest.

Több korábbi kutatás is a miénkhez hasonló eredményre jutott az alvás stabilizációs szerepével kapcsolatban, különböző emlékezeti rendszerek vonatkozásában [például az explicit (történet felidézése) ${ }^{37}$ vagy implicit (motoros szekvencia feladat) memória esetében ${ }^{38}$. Lewis és munkatársai ${ }^{39}$ a kontextuális memória kapcsán vizsgálták az alvás hatását. Személyeiknek a tanulási fázisban semleges tárgyat mutattak semleges vagy negatív háttér előtt, majd alvást vagy ébrenlétet követôen a tárgy ismételt bemutatásakor a megfelelő hátteret kellett felidézniük. A szerzők kisebb mértékú felejtést találtak - érzelmi telítettségtől függetlenül - azoknál a vizsgálati személyeknél, akik a feladatot követően aludtak, mint akik ezt az idôt ébren töltötték. Ez a csökkent felejtési ráta a bal hippocampus, valamint a superior parietalis kéreg aktivitásával mutatott kapcsolatot. Ezek a vizsgálatok mind arra mutattak rá, hogy az alvás optimális ideje lehet az emléknyomok stabilizálódásának, mert ideje alatt relatíve kisebb az interferencia, így az újonnan kódolt információk átszerveződése és rögzülése zavartalanabbul történhet a már meglévő emléknyomokat tartalmazó hálózatban ${ }^{40}$.

Kutatásunk során az asszociációs memória múködését vizsgáltuk, amit korábbi kutatások szintén a hippocampushoz kötnek ${ }^{41,42}$. Az asszociációs memóriafolyamatok olyan rugalmas tanulási és emlékezeti mechanizmusokat takarnak, amelyek lehetővé teszik a már meglévő információk összekapcsolását, kivonatolását és ezek mentén olyan általánosítások, illetve konceptuális sémák kialakítását, amelyek hozzájárulnak az absztrakt gondolkodási folyamatokhoz ${ }^{41}$. Az alvás tehát nemcsak a hosszú távú rögzülési folyamatban érintett, hanem vannak olyan feltételezések, hogy ugyanez a neuralis aktivitás felelős ébrenlét során, de főképp alvás alatt a már meglévő információk közötti relációk feltérképezéséért. Tehát ez az alvás alatti hippocampalis feldolgozás nemcsak az egyedi emlékek megszilárdulásában játszik közre, hanem az egyes emlékek összekapcsolásában és ezek flexibilis alkalmazásában is ${ }^{41-43}$.

Vizsgálatunk során összefüggést találtunk a tanulási és felidézési teljesítmény, valamint az elmúlt egy hónapra vonatkozó szubjektív alvásminőség, az alváslatencia és az alváshatékonyság között. Erdemes kiemelni, hogy a tanulási és felidézési teljesítmény összefüggést mutatott az ezeket megelőző alvásminőséggel is, ami arra utal, hogy az alvásunk meghatározza a következő napi teljesítményünket. Ezek az összefüggések arra mutatnak rá, hogy a konszolidációs folyamatban nemcsak az számít, hogy az alvás a tanulást követően történjen ${ }^{3-5}$, hanem a tanulás előtti alvásnak is fontos szerepe van, hiszen annak ideje alatt van lehetősége a központi idegrendszernek felkészülni a következő napra, a következő nap során érkezô információk kódolására. Megfelelố minôségú alvás hiányában már a megtanulni kívánt információk kódolása is zavart szenvedhet, ami befolyásolja a későbbi felidézési teljesítményt ${ }^{44}$. Ezt támasztják alá azok a vizsgálatok is, amelyek éjszakai alvásdeprivációt követôen a tanulás során alulmúködést mutattak ki a kódolásához kapcsolódó mediotemporalis lebenyben, illetve a hippocampus posterior területeinek aktivitásában, amelyek az alacsonyabb teljesítménnyel függtek össze ${ }^{45,46}$.

Mindkét csoport esetében két alkalommal történt a tanult anyag tesztelése, közvetlenül a tanulást követően, majd 24 órával később. Az esti csoport kisebb felejtési rátája alátámasztja azokat a korábbi szakirodalmi előzményeket, amelyek az alvás és 
tesztelési hatás témakörében születtek. Ezek alapján, a többszörösen tesztelt információkat kevésbé felejtjük el ${ }^{47}$, illetve az alvás a többször gyakorolt elemek esetében jobban segítheti a stabilizációs folyamatot, jobb teljesítményt eredményezve. A kevesebbszer ismételt ingerek a felejtést facilitálják, ezáltal téve hatékonyabbá az emlékezeti múködést ${ }^{48}$.

Az érzelmi valencia tekintetében korábbi kutatások a szaliens ingerekre való érzékenységet hangsúlyozzák. Vizsgálatunkban mindkét csoportnál a negatív arckifejezések esetében sikerült a legkevésbé a nevekkel való társítás, alacsonyabb teljesítmény jelent meg mindkét felidézési fázisban a semleges és pozitív érzelmi arckifejezésekhez képest. Hasonló kutatások szintén a pozitív arcok esetében mutattak ki jobb emlékezeti teljesítményt, amit a pozitív arcok jutalmazó jellegével magyaráztak a szerzôk ${ }^{19-22}$. Más vizsgálatok viszont a negatív érzelmi ingerek esetében mutattak ki jobb teljesítményt, azonban fontos megjegyezni, hogy ezek a kutatások nem arc-név tesztet használtak, hanem szólistát ${ }^{14,16}$ vagy tárgyképeket ${ }^{12,17}$. Így felmerül a kérdés, akárcsak az implicit tanulás esetében ${ }^{49}$, hogy az alvás esetleg eltérô hatást fejt-e ki annak függvényében, hogy milyen paradigmával (alvás vagy alvásdepriváció) vagy milyen ingeranyaggal dolgozunk (arcok-nevek, csak érzelmi arckifejezések, szólisták vagy tárgyképek). Lehet, hogy robusztusabb alváshatást kaphattunk volna, ha intenzívebb érzelmeket jelenítünk meg (például: szomorú arc helyett síró arc) az alkalmazott feladatunk során. Hasonló következtetésre jutottak Wagner és munkatársai ${ }^{50}$, akik vizsgálatában a résztvevôknek érzelmileg telített (boldog és szomorú), illetve semleges arcokra kellett emlékezniük úgy, hogy az egyik csoport a feladatot követően aludhatott, a másik csoport ébren volt. A két nappal késôbbi újratesztelésen jobb teljesítményt mutatott az alvós csoport (magasabb találati arány, kevesebb helytelen azonosítás) az ébrenléti csoporthoz képest, azonban eredményeinkhez hasonlóan ôk sem találtak különbséget az érzelmeket mutató és a semleges arckifejezésekre való emlékezésben a két csoport között.

Vizsgálatunk limitációja, hogy a szubjektív alvásminőség vizsgálatára kérdő́iveket alkalmaztunk. Érdemes lenne a jövőben kiegészíteni az adatokat éjszakai poliszomnográfiás mérésekkel, amelyek tovább árnyalhatják a képet az alvás szerepének feltérképezésében a tanulási és emlékezeti konszolidációs folyamatokban. Továbbá, habár a csoportok között nem volt különbség az azonnali és a késleltetett felidézésben, illetve kérdőívekkel kontrolláltuk a napközbeni fáradtságot, a jövőben a napszaki hatások kizárása érdekében érdemes lenne egy olyan további csoport bevonása, ami reggel tanul és még aznap este történik a felidézés.

Összefoglalva, vizsgálatunk során azt találtuk, nem mindegy, hogy mikor tanulunk és ehhez képest mikor következik be a következő alvási szakasz, ami fokozhatja az emléknyomok stabilizációját, kisebb mértékú felejtést eredményezve. Alvás alatt a frissen szerzett információk beépülhetnek a már meglévő információkat tartalmazó hálózatba, ami nemcsak hatékonyabb emlékezeti múködést, hanem egy flexibilisebb, absztraktabb gondolkodást is eredményezhet. Az alvás ilyen jellegú jótékony hatását korábbi kutatások már próbálták beépíteni idősek $^{44}$ vagy szkizofrén betegek ${ }^{45}$ terápiás protokolljába. Ennek alapján érdemes végiggondolni, hogyan lehetne az alvás hatását kamatoztatni a memória- és/vagy érzelemfelismerési zavarral rendelkezó kórképek rehabilitációjában.

\section{IRODALOM}

1. Oudiette D, Paller KA. Upgrading the sleeping brain with targeted memory reactivation. Trends in Cog Sci 2013;17(3):142-9.

https://doi.org/10.1016/j.tics.2013.01.006

2. Landmann N, Kuhn M, Piosczyk H, Heige B, Baglioni C, Spiegelhalder $K$, et al. The reorganization of memory during sleep. Sleep Med Rev 2014;18:531-41. https://doi.org/10.1016/j.smrv.2014.03.005

3. Gais J, Lucas B, Born J. Sleep after learning aids memory recall. Learn \& Mem 2006;13:259-62. https://doi.org/10.1101/lm.132106

4. Mather M, Knight M. Goal-directed memory: the role of cognitive control in older adult's emotional memory. Psychol and Aging 2005;20:554-70.

https://doi.org/10.1037/0882-7974.20.4.554

5. Szôllősi Á, Keresztes A, Conway M, Racsmány M. A diary after dinner: How the time of event recording influences later accessibility of diary events. Quater J of Exp Psychol 2015;68(11):2119-24.

https://doi.org/10.1080/17470218.2015.1058403

6. Diekelman S, Born J. The memory function of sleep. Nat Rev Neurosci 2010;11:114-26.

7. Diekelman $S$. Sleep for cognitive enhancement. Front in Syst. Neurosci 2014;8(46):1-12.

8. Born J, Wilhelm I. System consolidation of memory during sleep. Psychol Res 2012;76:192-203.

9. Atienza M, Cantero JL. Modulatiory effects of emotion and sleep of recollection and familiarity. J Sleep Res 2008; $17: 285-94$

https://doi.org/10.1111/j.1365-2869.2008.00661.x 
10. LaBar KS, Cabeza R. Cognitive neuroscience of emotional memory. Nat Rev Neurosci 2006;7:54-64. https://doi.org/10.1038/nrn1825

11. Bennion KA, Payne JD, Kensinger EA. Selective effect of sleep on emotional memory: What mechanism are responsible? Translat Issues Psychol Sci 2015;1(1):79-88. https://doi.org/10.1037/tps0000019

12. Payne JD, Kensinger EA, Wamsley E, Sprengl R, Alger $S$, Gibler $K$, et al. Napping and selective consolidation of negative aspects of scenes. Emotion 2015;15(2):176-86. https://doi.org/10.1037/a0038683

13. Lehman M, Seifritz E. Rasch B. Sleep benefits emotional and neutral associative memories equally. Somnologie 2016;20:47-53. https://doi.org/10.1007/s11818-015-0034-4

14. Csábi E, Zámbó A. Az alvás szerepe a tanulási és explicit emlékezeti folyamatokban az érzelmi telítettség függvényében. Iskolakultúra 2019;4-5:146-58.

15. Gais J, Lucas B, Born J. Sleep after learning aids memory recall. Learn and Mem 2004;13:259-62. https://doi.org/10.1101/lm.132106

16. Hu P, Stylos-Allan M, Walker MP. Sleep facilitates consolidation of emotional declarative memory. Psychol Sci 2006; 17:891-9. https://doi.org/10.1111/j.1467-9280.2006.01799.x

17. Wagner $U$, Gais $S$, Born J. Emotional memory formation is enhanced across sleep intervals with high amounts of rapid eye movement sleep. Learn and Mem 2001;8:112-9. https://doi.org/10.1101/lm.36801

18. Baran B, Pace-Schott EF, Ericson C, Spencer RMC. Processing of emotional reactivity and emotional memory over sleep. J Neurosci 2012;32(3):1035-42. https://doi.org/10.1523/jneurosci.2532-11.2012

19. Kaufman JM, Schweinberger SR. Expression influences the recognition of familiar faces. Perception 2004;33:399-408. https://doi.org/10.1068/p5083

20. Shimamura AP, Ross, JG, Bennett HD. Memory for facial expressions: The power of a smile. Psych Bull Rev 2006; 13:217-22.

21. Tsukiura T, Cabeza R. Orbitofrontal and hippocampal contributions to memory for face-name assocations: The rewarding power of a smile. Neuropsy 2008;46:2310-9. https://doi.org/10.1016/j.neuropsychologia.2008.03.013

22. Winston JS, Strange BA, O'Doherty J, Dolan DJ. Autmatic and intentional brain responses during evaluation of trustworthiness of face. Nat Neurosci 2002;5:277-83. https://doi.org/10.1038/nn816

23. Öhman A, Lundqvist D, Esteves $F$. The face in the crowd revisited: A threat advantage with schematic stimuli. J Pers and Soc Psy 2001;80:381-96.

https://doi.org/10.1037/0022-3514.80.3.381

24. Minkel J, Htaik O, Banks S, Dinges D. Emotional Expressiveness in sleep-deprived healthy adults. Behav Sleep Med 2011;9:5-14. https://doi.org/10.1080/15402002.2011.533987

25. Killgore WDS, Nalkin TJ, Yarnell, AM, Capaldi VF. Sleep deprivation impairs recognition of specific emotions. Neurobiol Sleep and Circ Rythm 2017;3:10-6. https://doi.org/10.1016/j.nbscr.2017.01.001

26. Maccari L, Martella D, Marotta A, Sebastiani M, Banaj N, Fuentes LJ, Casagrande M. Effects of sleep loss on emotion recognition: dissociation between face and word stimuli. Exp. Brain Res 2014;232:3147-57. https://doi.org/10.1007/s00221-014-3995-9

27. Pallesen S, Johnsen BH, Hansen A, Eid J, Thayer JF, Olsen T, Hugdahl K. Sleep deprivation and hemispheric assymetry for facial recognition reaction time and accuracy. Percep and Motor Skill 2004;98:1305-14. https://doi.org/10.2466/pms.98.3c.1305-1314
28. Racsmány M, Lukács Á, Németh D, Pléh Cs. A verbális munkamemória magyar nyelvú vizsgálóeljárásai. Magyar Pszichológiai Szemle 2005;LX(4):479-505. https://doi.org/10.1556/mpszle.60.2005.4.3

29. Buysse DJ, Reynolds CF, Monk TH, Berman SR, Kupfer $D J$. The Pittsburgh sleep quality index: A new instrument for psychiatric practice and research. Psyc Res 1989;28 (2): $193-213$ https://doi.org/10.1016/0165-1781(89)90047-4

30. Simor P, Köteles $F$, Bódizs R, Bárdos Gy. A szubjektív alvásminőség kérdőíves vizsgálata: a Groningen Alvásminőség Skála hazai validálása. Mentálhigiéné és Pszichoszomatika 2009;10(3):249-61. https://doi.org/10.1556/mental.10.2009.3.5

31. Zavecz. Zs, Török Cs, Köteles F, Pálosi V, Simor P. A MEQ-H (MorningnessEveningness Questionnaire) hazai adaptációjának pszichometriai jellemzői: a Reggeli éberség és a Napszaki ritmus elkülönülő faktorai. Psychi Hung 2015;30(3):318331.

32. Hoddes E, Zarcone V, Smythe H, Phillips R, Dement WC. Quantification of sleepiness: a new approach. Psychophysiol 1973;10(4):431-6. https://doi.org/10.1111/j.1469-8986.1973.tb00801.x

33. Smith KJ, Mullally S, McLoughlin D, O'Mara S. Validation of the face-name pairs task in major depression: impaired recall but not recognition. Fronti in Psychol 2014;5(92):1-6. https://doi.org/10.3389/fpsyg.2014.00092

34. Minear M, Park DC. A lifespan database of adult facial stimuli. Behav Res Meth, Instr, \& Comp 2004;36:630-3.

35. Ebner N. Age of face matters: Age-group differences in ratings of young and old faces. Behav Res Meth 2008;40 (1):130-6 https://doi.org/10.3758/brm.40.1.130

36. Tottenham N, Tanaka JW, Leon AC, McCarry T, Nurse M, Hare TA, et al. The NimStim set of facial expressions: Judgments from untrained research participants. Psych Res 2009; 168(3):242-9. https://doi.org/10.1016/j.psychres.2008.05.006

37. Wagner U, Hallschmid, E, Rasch B, Born J. Brief sleep after learning keeps emotional memories alive for years. Biol Psych 2006;60:788-90. https://doi.org/10.1016/j.biopsych.2006.03.061

38. Nettersheim A, Hallschmid E, Born J, Diekelmann S. The role of sleep in motor sequence consolidation: stabilization rather enhancement. J of Neurosci 2015;35(17):6696-702. https://doi.org/10.1523/jneurosci.1236-14.2015

39. Lewis PA, Cairney S, Manning L, Critchley HD. The impact of overnight consolidation upon memory for emotional and neutral encoding contexts. Neuropsych 2011;49: 2619-29. https://doi.org/10.1016/j.neuropsychologia.2011.05.009

40. Ellenbogen JM, Hulbert JC, Stickgold R, Dinges DF, Thompson-Schil SL. Interfering with theories of sleep and memory: sleep, declarative memory, and associative interference. Curr Biol 2006;16:1290-4. https://doi.org/10.1016/j.cub.2006.05.024

41. Ellenbogen JM, Hu PT, Payne JD, Titone D, Walker MP. Human relational memory requires time and sleep. PNAS 2007; 104:7723-8. https://doi.org/10.1073/pnas.0700094104

42. Eichenbaum H. Hippocampus: Cognitive processes and neuronal representations that underlie declarative memory. Neuron 2004;44:109-20.

43. van Dongen EV, Thielen JV, Takashima A, Barth $M$, Fernández $G$. Sleep supports selective retention of associative memories based on relevance for future utilization. PlosOne 2012; 7:e43426. https://doi.org/10.1371/journal.pone.0043426 
44. Mander BA, Santhanam S, Saletin JM, Walker MP. Wake deterorientation and sleep restoration of human learning. Curr Biol 2011;21(5):R183-R184. https://doi.org/10.1016/j.cub.2011.01.019

45. Yoo $S, H$ u P, Gujar N, Jolesz F, Walker M. A deficit in the ability to from new human memories without sleep. Nat Neurosci 2007; 10:385-92. https://doi.org/10.1038/nn1851

46. Prince TM, Wimmer M, Choi J, Havekes R, Aton S, Abel T. Sleep deprivation during a specific 3-hour time window post-training impairs hippocampal synaptic plasticity and memory. J Neurbiol Learn Mem 2014;109:122-30. https://doi.org/10.1016/j.nlm.2013.11.021

47. Roediger HL, Karpicke JD. Test - enhanced learning: taking memory tests improves long-term retention. Psychological Science 2006;17:249-55. https://doi.org/10.1111/j.1467-9280.2006.01693.x

48. Racsmány M, Conway M, Demeter Gy. Consolidation of episodic memories during sleep: long-term effect of retrieval practice 2009;21:80-5. https://doi.org/10.1177/0956797609354074

49. Csábi E, Németh $D$. Az alvás szerepe az implicit tanulási folyamatokban. Ideggy Sz 2014;67(1-2):9-18.

50. Wagner U, Kashyap N, Diekelmann S, Born J. The impact of post-learning sleep vs. wakefulness of recognition memory for faces with different facial expression. Neurobiol Lear Mem 2007;87:679-87. https://doi.org/10.1016/j.nlm.2007.01.004 